\title{
REPRESENTASI PENDIDIKAN KARAKTER DALAM FILM SURAU DAN SILEK (ANALISIS SEMIOTIK FERDINAND DE SAUSSURE)
}

\author{
Putra Chaniago, S. Sos \\ Magister Komunikasi Penyiaran Islam UIN Sunan Kalijaga Yogyakarta \\ J1. Marsda Adisucipto Yogyakarta 55281 \\ e-mail : pchaniago70@gmail.com
}

\begin{abstract}
Abstrak : Penelitian ini membahas tentang nilai-nilai pendidikan karakter dalam ranah komunikasi Islam pada Film Surau dan Silek. Jenis penelitian ini adalah deskriptif kualitatif dengan menggunakan metode analisis semiotika Ferdinan de Saussure. Dalam metodenya ia mengembangkan dua sistem yaitu penanda, pertanda serta makna yang terkandung dan yang ingin disampaikan di dalamnya. Film ini merupakan film budaya berbahasa Minangkabau yang mengandung tutur nasihat. Film ini bercerita tentang kehidupan tiga remaja Minang yang sedang semangat berlatih silat, namun mereka ditinggalkan oleh Mak Rustam sang guru silat yang memutuskan untuk pergi merantau. Penelitian ini menemukan terdapat representasi pendidikan karakter dalam film surau dan silek, yaitu silek mengajarkan kesimbangan antara emosional question (kecerdasan emosional), spiritual question (kecerdasan spritual), intelegens question (kecerdasan intelejen) dan heart question (kecerdasan hati). Film Surau dan Silek mengandung banyak pesan moral, nilai-nilai agama dan budaya, sehingga mampu merubah persepsi tentang silat di Minang yang tak hanya sebagai aktifitas pemuda nagari untuk berkelahi, namun juga sebagai pendidikan karakter dari perspektif Islam dan adat Minang, yaitu mengamalkan agama Islam sebagai ajaran, dan melestarikan budaya surau dan silat sebagai aktifitas pemuda Minang.
\end{abstract}

\begin{abstract}
This study discusses the value of character education values in the realm of Islamic communication studies in Surau and Silek films. This type of research is descriptive qualitative using the semiotic analysis method of Ferdinand de Saussure. In his method, he developed two systems, namely the signifier, the sign and the meaning that is contained and what is intended to be conveyed in it. This film is a cultural film in Minangkabau language which contains advice speech. This film tells the story of the lives of three Minang teenagers who are passionate about practicing silat, but they are left behind by Mak Rustam, the silat teacher, who decides to leave. In this study, it was found that there is a representation of character education in the surau and silek films, namely silek teaching a balance between emotional questions (emotional intelligence), spiritual questions (spiritual intelligence), intelligent questions (intelligence intelligence) and heart questions (intelligence). The Surau and Silek films contain many moral messages, religious and cultural values, so that they are able to change the perception of silat in Minang which is not only an activity of village youth for fighting, but also as character education from the perspective of Islam and Minang customs, namely practicing Islam. as teaching, and preserving the culture of surau and silat as Minang youth activities.
\end{abstract}

Kata Kunci : Semiotika, Representasi Pendidikan Karakter, Surau, Silek 
Journal of Islamic Education Policy Vol. 4 No. 2 Juli - Desember 2019

\section{Pendahuluan}

Surau dan silek merupakan bagian dari keunikan dan kearifan lokal yang dimiliki oleh alam Minangkabau. Kedudukan Surau selain pusat peribadatan (ibadah mahdhah), juga menjadi pusat pendidikan, pengajaran dan pembentukan karakter pemuda agar berbudi luhur dan ber-aklakul karimah. Selain itu juga ada silek atau silat yang berfungsi sebagai benteng dan jati diri pemuda Minang. Sehingga surau dan silek menjadi satu kesatuan yang tidak bisa dipisahkan dari sosiologis masyarakat Minangkabau.

Sudah menjadi kebiasaan dari sejak dahulu di Minangkabau, bahwa pemuda diwaktu malam hari selalu datang ke surau. Disamping melaksanakan sholat, mereka belajar mengaji, belajar pidato adat, dan berlatih silek atau silat sebagai suatu kemampuan yang harus dikuasai oleh pemuda. Silat tidak hanya di pandang sebatas nilai olahraga atau kemampuan berkelahi adu fisik semata, namun juga menjadi sarana pendidikan moral, akhlak, dan kepribadian pemuda Minangkabau. Hal tersebut menjadi sebuah tradisi, apabila seorang anak laki-laki telah memasuki usia baligh, maka mereka telah di katakan menjadi seorang pemuda. Tidurnya bukan lagi dirumah, akan tetapi seorang pemuda tidurnya adalah di surau atau ada juga yang di lapau. Dengan sendirinya, si pemuda akan merasa malu apabila masih tidur dirumah. Sehingga dengan adanya mitos seperti ini, membuat pemuda tak betah berlamalama dikampung, kebanyakan mereka memutuskan untuk pergi merantau, dalam rangka menutut ilmu, mencari penghidupan yang lebih baik ataupun bekerja di negeri orang.

Minangkabau memiliki budaya pendidikan karakter yang khas, yaitu budaya pendidikan surau. Meski secara historis, keberadaan surau lebih dahulu ada sebelum kedatangan Islam di Minangkabau. Pendidikan surau artinya pendidikan yang dilaksanakan dalam suatu kawasan pusat peribadatan; Masjid, Mushala, Langgar, yang dalam bahasa Minang disebut surau. Pendidikan yang diajarkan di surau yaitu beriorientasi pada nilai-nilai agama Islam dan adat istiadat Minangkabau serta pengamalannya dalam kehidupan seharihari, seperti; sumbahyang (sholat), mangaji, mangecek (berbicara/pidato adat) dan basilek (bersilat). Pendidikan dalam lingkungan surau merupakan faktor eksternal yang membentuk karakter dan kepribadian masyarakat Minang. Ukuran penilaian keberhasilannya bukanlah hasil belajar berupa angka, melainkan diwujudkan dalam bentuk sikap dan perilaku.

Namun seiring berjalannya waktu serta pengaruh kuatnya arus modernisasi, mengakibatkan eksistensi surau dan silek berangsur redup dan hilang. Keberadaan Surau mulai memprihatinkan dengan kondisi pemuda yang mulai acuh, meninggalkan surau dan melupakan silek sebagai bagian dari hidup atau tradisi mereka. Begitu banyak ancaman dekadensi moral, pengaruh dari budaya luar yang bertentangan dengan nilai dan norma, termasuk tontonan, akses media sosial yang semakin mudah cenderung menggerogoti bahkan merusak pemuda Minang.

Kuatnya penetrasi yang datang dari luar, serta lemahnya semangat menjalankan perintah agama, menyebabkan kemerosotan moral dan spiritual pemuda-pemuda Minang. Hal 
ini menimbulkan keperihatinan bagi kalangan ulama, dan tokoh masyarakat Minangkabau. Mereka berpendapat bahwa hilangnya akhlak, umumnya disebabkan akibat agama tidak diamalkan, ibadah lalai, nilai etika budaya yang diabaikan. ${ }^{1}$ Tentunya ini sangat berpengaruh pada tatanan nilai dan norma di masyarakat. Tumbuhnya kebiasaan bolos sekolah, malas belajar, tawuran antar pelajar dan semacamnya. Bahkan juga di kampung dan di Nagari juga terdapat pula keengganan menjadikan surau sebagai pusat pendidikan. Buya Mas'ud Abidin mengatakan bahwa keadaan tersebut berakibat kepada bergesernya kendali dan arena pembinaan from the mosque to the mall (dari surau pindah ke lapau)menjadi suatu hal yang amat menakutkan. Gejala generasi muda di nagari diantaranya ada terjangkiti perangai permissivisme terbawa arus postmodernisme. Keganasan mulai melanda kalangan muda. Mereka mulai larut kedalam tindakan anarkisme. $^{2}$

Dalam perjalanan serah terima generasi Minangkabau di masa kini, kita menatap fenomena peralihan yang mencemaskan. Jika tidak teratasi akan menjadi buah ratapan di masa yang akan datang. Maka perlu adanya upaya persuasif dan edukatif yang mesti dilakukan menyesuaikan kondisi zaman dan kekinian, salah satunya melalui tontonan atau film. Budaya asli memang semestinya dipertahankan, namun tidak menolak sepenuhnya kemajuan ilmu pengetahuan yang ada. Maka perlu adanya upaya penyadaran dan penyesuaian terhadap kondisi yang terjadi dengan sebuah karya seni melalui film.

Perfilman di Indonesia dikatakan sudah berkembang. Berdasarkan hasil survey yang dilakukan Fimela pada tahun 2019 menyakatan bahwa dunia perfilman di Indonesia mengalami perkembangan yang begitu pesat Hal ini dapat dilihat dari konsistennya peningkatan jumlah penonton dan film yang tayang di bioskop-bioskop Indonesia dari tahun 2016 sampai $2019 .^{3}$

Film Surau dan Silek adalah sebuah film yang bernuansa keagamaan dan kebudayaan Minangkabau. Film ini berhasil meraih penghargan BISA (Be Indonesia Smart And Active) pada acara Hongkong Film Award 2017. Arul Husen dari BISA Care mengatakan selain memiliki sinematografi yang sagat baik dan berkualitas ia juga berusaha mengangkat kearifan lokal dengan 90 persen menggunakan bahasa Minangkabau. ${ }^{4}$

Jenis penilitian ini adalah analisis kualitatif. Metode penelitian ini menggunakan pendekatan kualitatif karena dalam pelaksanaannya dilakukan dalam pemaknaan teks, dari pada penjumlahan kategori. Pengumpulan data melalui reseacrh document, kemudian datadata di analisis melalui struktur semiotika ferdinan de saussure. Objek penelitiannya adalah Film Surau dan Silek yang di unduh dari youtube, penelitian pada peran tokoh utama dalam

\footnotetext{
${ }^{1}$ H. Mas'oed Abidin, Tiga Sepilin, Suluah Bendang Dalam Nagari. (Yogyakarta: CV Gre Publishing, 2016), h. 89

${ }^{2}$ H. Mas'oed Abidin, Tiga Sepilin, Suluah Bendang ..., h. 90

${ }^{3}$ Silmy Hayati, Dkk, "Struktur Tindak Tutur Nasihat Yang Terdapat Dalam Film Surau Dan Silek" LINGUISTIK: Jurnal Bahasa \& Sastra, Vol. 5 No.1 Januari-Juni 2020, h. 101-113

${ }^{4}$ Silmy Hayati, Dkk, "Struktur Tindak Tutur Nasihat Yang Terdapat Dalam Film Surau Dan Silek" LINGUISTIK: Jurnal Bahasa \& Sastra, Vol. 5 No.1 Januari-Juni 2020, h. 101-113
} 
Journal of Islamic Education Policy Vol. 4 No. 2 Juli - Desember 2019

film yang dibingkai oleh sang sutradara. Film merupakan salah satu media massa yang berpengaruh dalam perubahan konstruksi pola pikir khalayak. ${ }^{5}$

Film ini pernah diteliti sebelumnya oleh Dynia Fitri, mahasiswi pascasarjana ISI padang panjang, pada tahun 2018 dengan judul Representasi Ideologi Minangkabau Dalam Film Surau dan Silek Ditinjau Dari Kajian Semiotika ${ }^{6}$. Penelitian tersebut terfokus pada representasi ideologi minangkabau yang terdapat dalam film surau dan silek melalui analisis semiotika roland Barthes. Sementara pada penelitian ini, penulis lebih memfokuskan penelitian pada kajian analisis semiotika dalam rangka meninjau pendidikan karakter yang terdapat dalam film surau dan silek melalui model analisis Ferdinand de Sausure.

\section{Kajian Teori}

\section{Semiotika}

Apabila kita mengamati sesuatu, maka tidak terlepas dari makna, persepsi dan pemahaman kita terhadap apapun yang kita lihat. Ketika kita mengendarai sepeda motor di jalan raya, maka kita bisa memaknai setiap kali kita mengamati lampu lalu lintas di traffic light, atau tanda "Dilarang parkir" dan berbagai macam tanda-tanda lainnya. Maka kitapun juga akan bertanya-tanya, kenapa setiap tanda dan simbol yang kita lihat itu dapat dimaknai dan disepakati secara bersama-sama?. Nah, pertanyaan itu akan dijawab dalam kajian keilmuan yang meneliti tentang tanda, dan konstruksi makna yang terdapat didalam tanda tersebut yang dinamakan semiotika.

Semiotika adalah studi mengenai tanda (sign) dan simbol. Tradisi semiotika mencakup teori utama yaitu mengenai bagaimana tanda mewakili objek, ide, situasi, keadaan, perasaan, dan sebagainya yang berada diluar diri. Studi ini tidak hanya memberikan jalan mengenai cara mempelajari komunikasi tapi juga memiliki efek besar pada hampir setiap aspek dalam teori komunikasi. ${ }^{7}$

Ilmu semiotik atau semiologi merupakan ilmu yang membahas atau mengkaji mengenai pemaknaan dari sebuah tanda. ${ }^{8}$ Semiotik bertujuan untuk mengetahui maknamakna yang terkandung dalam sebuah tanda atau menafsirkan makna tersebut sehingga diketahui bagaimana komunikator mengkonstruksi pesan. Konsep pemaknaan ini tidak terlepas dari perspektif atau nilai-nilai ideologis tertentu serta konsep kultural yang menjadi ranah pemikiran masyarakat dimana simbol tersebut diciptakan. Kode kultural yang menjadi salah satu faktor konstruksi makna dalam sebuah simbol menjadi aspek yang penting untuk

\footnotetext{
${ }^{5}$ Lailatul Mufarihah, "Representasi Gender Dalam Film Tenggelamnya Kapal Van Der Wijk (Analisis Framing Model William A Gamson dan Andre Modigalani)" JURNAL ILMU KOMUNIKASI, Vol. 9 No. 1, April 2019

${ }^{6}$ Dynia Fitri, Representasi Ideologi Minangkabau Dalam Film Surau dan Silek Ditinjau Dari Kajian Semiotika. Jurnal Layar Volume V. 2 Desember 2018

${ }^{7}$ Morissan, Teori Komunikasi Individu Hingga Massa, (Jakarta: Kencana, 2013), h. 31

${ }^{8}$ Arif Budi Prasetya, Analisis Semiotika Film dan Komunikasi, (Malang: Intrans Publishing, 2019), h. 
mengetahui konstruksi pesan dalam tanda tersebut. Konstruksi makna yang terbentuk inilah yang kemudian menjadi dasar terbentuknya ideologi dalam sebuah tanda. ${ }^{9}$

Konsep dasar dari semiotika adalah mempelajari tanda yang memiliki makna, tentunya harus relevan dengan kebutuhan masyarakat. Sehingga keberadaan budaya yang sarat dengan nilai, norma dan segala bentuk aturannya, tidak bisa kita kesampingkan begitu saja. Beberapa hal yang perlu diperhatikan dalam melakukan kajian terhadap tanda adalah pemahaman bahwa tanda tidak bisa berdiri sendiri. Mereka memerlukan bantuan penyematan makna. Tanda tanpa makna hanya sebuah objek visual yang tidak berarti apapun. Orang hanya akan melihat bahwa itu adalah sebuah objek tanpa arti apapun, tidak bisa dikomunikasikan. Hal ini disebabkan bahwa manusia memiliki gambaran mengenai objek, peristiwa serta makna terhadap peristiwa tersebut, yang diawali dengan konsep visualisasi. Dengan adanya kemampuan bervisualisasi dan merekam memori dalam otak, manusia mampu memahami berbagai bentuk peristiwa yang terjadi disekitarnya. ${ }^{10}$ Konsep pemikiran dari orang yang menggunakan tanda dan menurunkannya ke suatu makna tertentu atau makna yang ada dalam benak seseorang tentang objek yang dirujuk sebuah tanda. ${ }^{11}$

Pengamatan terhadap sebuah tanda tak ubahnya mengamati sebuah makna atau maksud kenapa, mengapa dan bagaimana benda tersebut eksis. Tanda yang menjadi aspek utama dalam pemikiran semiotik, oleh Peirce "diperlakukan" sebagai sebuah poros dalam segitiga makna. Maksud dari sebagai poros disini merupakan sebuah pemikiran utama yang tidak terlepas dari hubungan antar manusia, makna dan objek yang diamati.

\section{Budaya dan Kebudayaan}

Semiotika merupakan ilmu yang mempelajari tanda dan makna-makna didalam tanda. Tanda bersifat dinamis, dan memiliki keberagaman dalam memaknainya. Tanda terbagi kedalam dua aspek, yaitu penanda (signifier) sebagai aspek yang memberikan makna, atau memberikan sebuah status terhadap simbol sehingga simbol tersebut memiliki arti sehingga dapat dimaknai dan petanda (signified) merupakan konsep general dimana makna diberikan kepada suatu tanda atau simbol. Konsep ini dalam semiotika dinamakan pertandaan atau signifikasi. Semua itu merupakan ranah bagi cultural studies untuk mengkaji lebih dalam lagi suatu budaya populer. ${ }^{12}$

Kajian Cultural Studies merupakan suatu kajian mendalami pola perilaku masyarakat di era modern yang disejajarkan dengan pemikiran filsafat. Cultural Studies bukanlah ilmu yang berisikan teori, melainkan pemikiran yang berda di ranah interdisipliner dari ilmu-ilmu yang lain, bukan pula disiplin ilmu sendiri, melainkan sebuah perspektf dalam rangka mengkaji suatu budaya populer dalam masyarakat di era modern. Untuk mendeskrisikan budaya-budaya masyarakat massa, maka dapat dilihat menggunakan yaitu, tanda, bahasa, dan budaya itu sendiri. Tanda merupakan produk dari masyarakat yang memiliki makna tersendiri

\footnotetext{
${ }^{9}$ Arif Budi Prasetya, Analisis Semiotika Film dan Komunikasi, h. 5

${ }^{10}$ Arif Budi Prasetya, Analisis Semiotika Film dan Komunikasi, h. 7

${ }^{11}$ Arif Budi Prasetya, Analisis Semiotika Film dan Komunikasi, h. 16-17

${ }^{12}$ Arif Budi Prasetya, Analisis Semiotika Film dan Komunikasi, h. 24
} 
Journal of Islamic Education Policy Vol. 4 No. 2 Juli - Desember 2019

dan tentu saja hasil dari kesepakatan masyarakat tersebut untuk memaknainya. "A sign is anything which produces meanings" Tanda sendiri merupakan semua hal yang menghasilkan makna. ${ }^{13}$

Kajian dari cultural studies yang selanjutnya adalah mengenai bahasa. Bahasa merupakan alat yang memiliki fungsi beragam dan merambah berbagai aspek sosial budaya pada masyarakat. Culural Studies memberikan status kepada bahasa bahwa bahasa adalah alat kekuasaan. Bahasa dapat memberikan suatu konstruksi pola pikir terhadap suatu pihak, dengan bahasa seseorang dapat meraih kekuasaan dan melanggengkan kekuasaan tersebut. Makna yang terkandung di dalam bahasa merupakan bentuk dari konstruksi pemikiran pembuatnya dimana makna tersebut akan disampaikan melalui bentuk representasi yang beragam. Penerima atau receirver akan melakukan sebuah persepsiyang akan menghasilkan suatu perspektif tersendiri. ${ }^{14}$

\section{Film}

Film merupakan salah satu bentuk media massa audio visual yang sudah dikenal oleh masyarakat. Khalayak menonton film tentunya adalah untuk mendapatkan hiburan seusai bekerja, beraktifitas atau hanya sekadar mengisi waktu luang. Akan tetapi dalam film dapat terkandung fungsi informatif maupun edukatif, bahkan persuasif. ${ }^{15}$ Film adalah seonggok gambar hidup dari seonggok seluloid dan dipertunjukan melalui proyektor. Namun, dimasa sekarang film tidak hanya menggunakan pita seluloid (proses kimia), akan tetapi lebih pada pemanfaatan teknologi hidup.

Para politikus film menyatakan bahwa film adalah suatu perkembangan yang muncul dari fotografi. Foto tidak memiliki ilusi gerak (baca: statis), sedangkan pada film terdapat ilusi gerak (moving camera). Menurut Elvinaro Ardiyanto, film adalah gambar bergerak yaitu bentuk dominan dari komunikasi massa visual di belahan dunia ini. ${ }^{16}$ Film telah mengalami perkembanganya yang cukup pesat. Keberadaannya diawali dengan gambar bergerak berwarna hitam putih, hingga saat ini film telah memasuki suatu konsep audio visual dengan menggunakan teknologi canggih yang dikenal dengan sinema tiga dimensi (3D). Kecendrungan masyarakat untuk menikmati masa senggang dengan menyaksikan film. Film berperan sebagai sarana baru yang digunakan untuk menyebarkan hiburan yang sudah menjadi kebiasaan terdahulu, sermenyajikan cerita, peristiwa, musik, drama, lawak, dan sajian teknis lainnya kepada masyarakat umum. ${ }^{17}$

Film adalah gambar hidup juga sering disebut dengan movie. Gambar hidup adalah bentuk seni, bentuk popular dari hiburan dan juga bisnis. Film merupakan teknologi hiburan massa dan untuk menyebarluaskan informasi dan berbagai pesan dalam skala luas disamping

\footnotetext{
${ }^{13}$ Arif Budi Prasetya, Analisis Semiotika Film dan Komunikasi, h. 23

${ }^{14}$ Arif Budi Prasetya, Analisis Semiotika Film dan Komunikasi, h. 24

${ }^{15}$ H. Mas'oed Abidin, Tiga Sepilin, Suluah Bendang Dalam Nagari. (Yogyakarta: CV Gre Publishing, 2016), h. 145

${ }^{16}$ Elvinaro Ardiyanto, Komunikasi Massa Suatu Pengantar. (Bandung:Simbiosa Rakatama Media, 2007), h. 43

${ }^{17}$ Dennis McQuail, Teori Komunikasi Massa Suatu Pengantar, (Jakarta: Erlangga, 1994), h. 3
} 
pers, radio, dan televisi. ${ }^{18}$ Menurut Andre Garcies, sebagai media rekam film menyajikan gambar figuratif dalam bentuk objek-objek fotografis yang dekat dengan kehidupan manusia. ${ }^{19}$

Pengertian Film merujuk pada pendefinisian untuk tujuan hukum yang tercantum dalam Undang-Undang nomor 8 tahun 1992 tentang perfilman yaitu sebagai berikut,

1. Film adalah karya cipta seni dan budaya yang merupakan media komunikasi massa pandang-dengar yang dibuat berdasarkan asas sinematografi dengan direkam pada pita seluloid, pita video, dan/atau bahan hasil penemuan teknologi lainnya dalam segala bentuk jenis dan ukuran melalui proses kimiawi, proses elektronik atau proses lainnya, dengan atau tanpa suara yang dapat dipertunjukan dan/atau ditayangkan dengan sistem proyeksi mekanik, elektronik dan/atau lainnya.

2. Perfilman adalah seluruh kegiatan yang berhubungan dengan pembuatan, jasa, teknik, pengeksporan, pengimporan, pengedaran, pertunjukan dan/atau penayangan film.

Pengertian film dapat disederhanakan dari sifatnya sebagai moda komunikasi yaitu pandang-dengar (audio-visual) yang direkam dengan perangkat teknologi. Sifat teknologis melalui proses kimiawi dan elektronik media rekam, dapat berupa pita seluloid dan video magnetik, serta cakram optik atau bentuk lain. ${ }^{20}$

Kemampuan film dalam menyampaikan pesan terletak dari jalur cerita yang dikandungnya. ${ }^{21}$ Tanda-tanda yang ada pada sebuah film, yaitu berupa tanda yang tersurat dan ada tanda yang tersirat. Bahkan terkadang ada tanda yang dapat dibaca karena tanda tersebut tidak dapat di maknai secara langsung, baik itu dalam bentuk dialog, ataupun dalam bentuk adegan. Menurut Alex Sobur, pada umumnya film dibangun dengan banyak tanda, dan digunakannya tanda-tanda ikonis atau tanda-tanda yang menggambarkan sesuatu, ini menjadi hal yang penting pada sistem semiotika film. ${ }^{22}$

Film tidak hanya sekadar cerita fiktif semata, akan tetapi juga menjadi gambaran atas realitas yang terjadi ditengah masyarakat dalam tatanan kehidupan sosial suatu kelompok masyarakat, baik itu dalam bentuk imajinasi, ataupun realitas yang sebenarnya.

Sekian banyak pengertian film tersebut di atas, dapat disimpulkan bahwa film merupakan cerita atau realitas yang terjadi dalam kehidupan sehari-hari yang ditampilkan

\footnotetext{
${ }^{18}$ Sean McBride, Komunikasi dan Masyarakat Sekarang dan Masa Depan : Aneka Suara Satu Dunia (terj) (Jakarta: Balai Pustaka, 1983), h. 20

${ }^{19}$ Muslikh Madiyant, Sinema Sastra : Mencari Bahasa Di Dalam Teks Visual, Jurnal Humaniora, Volume XV, No.2/2003

20 Ashadi Siregar, Jalan Ke Media Film : Persinggahan Diranah Komunikasi-Seni Kreatif, (Yogyakarta : LP3Y, 2007), h.8

${ }^{21}$ Arif Budi Prasetya, Analisis Semiotika Film dan Komunikasi, (Malang: Intrans Publishing, 2019), h.

${ }^{22}$ Alex Sobur, Semiotika Komunikasi, (Bandung: Remaja Rosdakarya, 2016), h. 12
} 
Journal of Islamic Education Policy Vol. 4 No. 2 Juli - Desember 2019

berupa gambar bergerak melalui media elektronik audio-visual untuk dapat tersampaikan pada khalayak ramai.

\section{a. Perkembangan Film}

Film ditemukan pada akhir abad ke 19. Pada awalnya hanya dikenal film hitam putih tanpa suara. Film terus mengalami perkembangan seiring dengan perkembangan teknologi yang mendukung. Sejarah perfilman mencatat, bahwa film yang pertama kali di produksi di Indonesia adalah film berjudul lady van Java pada tahun 1926 di kota Bandung oleh seorang yang bernama David. Pada tahun 1930 muncullah film-film yang semakin merebak, diantaranya berjudul Lutung Kasarung, Si Conat dan Pareh. Namun film tersebut masih berupa film bisu. ${ }^{23}$

Peralatan produksi film juga mengalami perkembangan dari waktu ke waktu. Pada akhir tahun 1920-an mulai dikenal film bersuara, dan menyusul film warna pada tahun 1930an. ${ }^{24}$ Onong Utjana Efendy menjelaskan bahwa pada tahun 1953 diketengahkan sistem tiga dimensi, yaitu suatu sistem yang benar-benar menimbulkan kesan yang mendalam, karena apa yang dilihat penonton tidak lagi latar, sehingga terlihat tampak benar-benar seperti kenyataan. Pada tahun yang sama, perusahaan film 20 Century Fox memperkenalkan cinemascope dengan layarnya yang lebar. Sementara itu perusahaan film Paramount berhasil menampilkan sistem vista vison yang meskipun layarnya tidak selebar cinemascope tetapi gambar yang ditampilkan sangat tajam. ${ }^{25}$

\section{b. Jenis - jenis Film}

Pada dasarnya film dapat dikelompokkan menjadi dua kategori, yaitu : film cerita dan film noncerita. Film cerita adalah film yang diproduksi berdasarkan cerita yang dikarang dan dimainkan oleh aktor atau aktris. Pada umumnya film cerita bersifat komersial, yakni dipertunjukan di bioskop dengan harga karcis tertentu atau dipertunjukan di bioskop dengan harga karcis tertentu atau diputar di televisi dengan dukungan sponsor iklan tertentu.

Film Cerita terdiri dari beberapa jenis, yakni :

a. Film Drama, yaitu suatu kejadian atau peristiwa hidup yang hebat mengandung konflik pergolakan, clash atau benturan antara dua orang atau lebih. Sifat drama antara lain : romance, tragedy, dan comedy.

b. Film Realisme, yaitu film yang mengandung relevansi dengan kehidupan seharihari.

c. Film Sejarah, yaitu melukiskan tokoh-tokoh tersohor dan peristiwa besar yang dialami.

d. Film Horor/Misteri, yaitu mengisahkan cerita yang menyeramkan, mengupas terjadinya fenomena supranatural yang menimbulkan rasa wonder, heran, takjub dan takut.

e. Film Perang, yaitu menggambarkan kondisi dan situasi perperangan.

${ }^{23}$ Elvinaro Ardianto dan Lukiati Komala Erdinaya, Komunikasi Massa suatu Pengantar (Bandung: Simbiosa Rekatama Media, 2004), h.135

${ }_{25}^{24}$ Marseli Sumarno, Dasar-Dasar Apresiasi Film, (Jakarta: Grasindo, 1996), h. 9

${ }^{25}$ Marseli Sumarno, Dasar-Dasar Apresiasi Film, h. 12 
f. Film Anak, yaitu film mengupas kehidupan anak-anak.

Dalam pembuatan film-film cerita ini dibutuhkan proses pemikiran dan proses teknis. Proses pemikiran berupa pencarian ide, gagasan dan cerita yang akan digarap. Sedangkan proses teknis berupa keterampilan artistik untuk mewujudkan segala ide, gagasan atau cerita menjadi film yang siap ditonton. Oleh karena itu film cerita dapat dipandang sebagai wahana penyebaran nilai-nilai. ${ }^{26}$

Sedangkan film non-cerita merupakan kategori film yang mengambil kenyataan sebagai subjeknya. Jadi merekam kenyataan daripada fiksi tentang kenyataan. ${ }^{27}$ Film noncerita diantaranya film dokumenter dan film faktual. Film dokumenter adalah film yang hanya merekam kejadian tanpa mengolah lagi, seperti dokumentasi upacara pernikahan. Selain mengandung fakta, film dokumenter juga mengandung subjektifitas pembuat film. ${ }^{28}$ Film faktual atau disebut juga film berita (newsreel) yakni film berupa fakta-fakta peristiwa yang sungguh terjadi yang disajikan melalui televisi, dengan berita dan gambar yang bersifat informatif.

\section{c. Film Surau Dan Silek}

Film surau dan silek, merupakan salah satu karya Film Nusantara yang lahir dari buah kreatifitas sutradara berbakat tanah air, Muhammad Arif atau dikenal Arif Malin Mudo. Seorang pemuda berdarah Minangkabau yang menyelesaikan kuliah S2-nya di Institut Seni Indonesia (ISI) Surakarta. Surau dan Silek ini merupakan Judul Thesis dari tugas akhir Arif untuk meraih gelar Magister Seni (M.Sn) pada tahun 2016 lalu dan berhasil menjadikannya sebuah film yang bertema adat, tradisi dan budaya lokal Minangkabau di balut dengan nilainilai Islam.

Firman Allah menyebutkan,

"kamu adalah umat terbaik yang dilahirkan untuk manusia, menyuruh kepada yang ma'ruf dan mencegah dari yang munkar dan beriman kepada Allah. Sekiranya ahli kitab beriman, tentulah itu lebih baik bagi mereka, diantara mereka ada yang beriman, dan kebanyakan mereka adalah orang-orang yang fasik," ${ }^{29}$

Film ini terinspirasi dari problema surau sebagai pusat kegiatan masyarakat dan silek yang disalah artikan oleh sebagian pemuda dan anak-anak Minang. Film ini lebih mengedepankan nilai edukasi serta tinggi nilai estetika dengan menampilkan keindahan alam Minangkabau. Dari setiap scene-nya menampilkan lokasi-lokasi di wilayah Bukittinggi dan Payakumbuh, seperti Jam Gadang dan Ngarai Sianok di Bukittinggi, Padang Manggateh dan Lembah Harau di Payakumbuh membuat film ini terasa begitu kental dengan kearifan lokal dan budayanya, dibalut dengan menampilkan keindahan alam Minangkabau sehingga lebih eksotis, menarik wisatawan untuk datang ke ranah Minang.

\footnotetext{
${ }^{26}$ Marseli Sumarno, Dasar-Dasar Apresiasi Film, h.13

${ }^{27}$ Marseli Sumarno, Dasar-Dasar Apresiasi Film, h. 10

${ }^{28}$ Marseli Sumarno, Dasar-Dasar Apresiasi Film, h. 14

${ }^{29}$ Lihat QS. Ali Imran : 110
} 


\section{d. Sinopsis Film Surau dan Silek}

Di sebuah negeri di Minangkabau, ada Tiga sekawan Adil (13tahun), Kurip, dan Dayat adalah murid di perguruan silat yang dipimpin Rustam (27). Rustam adalah seorang pemuda kampung Baringin yang belum mempunyai pekerjaan tetap dan mengetahui sedikit teknik tentang silat, namun tidak dengan filosofinya. Pada sebuah laga final turnamen silat antar kampung, Adil dikalahkan oleh Hardi (13) dengan curang. Setelah tunamen itu usai, tiga sekawan Adil, Dayat, dan Kurip berlatih lebih giat untuk membalaskan dendam mereka pada turnament yang akan datang. Harapan mereka menjadi pupus ketika Rustam memilih pergi merantau. Kehidupan tiga sekawanpun bagaikan layang-layang putus. Dayat sibuk dengan kegemarannya makan dan bermain, Kurip sibuk dengan persiapan lomba pelajaran ilmu pengetahuan sosialnya. Sedangkan adil, adalah yang paling keras kehidupannya, hidup berdua bersama ibunya yang bekerja sebagai buruh jahit, sedangkan ayahnya sudah meninggal. Satu ceramah yang selalu diingat oleh adil, "doa anak yang saleh adalah salah satu dari tiga syarat seorang yang telah meninggal untuk masuk surga". Namun Karena beban hidup, Adil banyak menemui rintangan untuk menjadi anak saleh. Hal ini membuat Rani (13) yang diam-diam mengagumi Adil, menceritakan keadaan Adil pada kakeknya, Arman. Kakek Rani kemudian menganjurkan Rani untuk menemui Johar (62), seorang teman kakeknya yang baru beberapa waktu pulang kampung untuk menikmati masa tuanya bersama istri. Rani meminta tolong kepada Johar agar mengajarkan silat kepada teman-temannya, namun ditolak.

Sampai pada suatu ketika Erna, istri Johar menyadarkan yang membuat Johar harus menerima tawaran Rani tersebut. Adil, Dayat, dan Kurip akhirnya belajar silat kepada Johar dengan syarat harus mematuhi metode latihan yang diterapkan Johar. Mereka berlatih memulai dari falsafah silat di Minangkabau yaitu "Lahir silat mencari teman, Bathin silat mencari Tuhan". Johar kemudian mendaftarkan tiga muridnya. Disini Johar kembali bertemu dengan Masri, teman Johar semasa muda diperguruan silat. Masri tak lain adalah guru silat Hardi. Menjelang hari pertandingan, Johar dihadang oleh Masri. Masri menyerang Johar menggunakan kurambik (senjata tajam) sampai Johar bercucuran darah. Johar terbaring di Rumah Sakit. Hari pertandingan, Adil dan Dayat hanya berdua di Sporthall diantara ratusan peserta. Kurip tak terlihat, karena memilih untuk ikut kompetisi ilmu sosial. Adil dan Dayat maju satu persatu. Dayat kalah pada dua laga yang diikutinya, Adil menang pada tiga pertandingan, dan kalah saat kembali berhadapan dengan Hardi. Sampai pada akhirnya tak disangka Kurip datang sesuai jadwal pertandingannya. Kurip terus menang hingga akhirnya kalah saat melawan Hardi di semi final. Kecurangan demi kecurangan dilakukan oleh Hardi untuk mengalahkan Adil di partai final. Sempat Adil terpancing dengan permainan busuk Hardi. Namun Rani, Kurip, dan Dayat mencoba menyadarkan Adil bahwa Johar mengajarkan bahwa hakikat silat adalah "mencari kawan dan mencari tuhan". Adil sadar bahwa sesungguhnya kemenangan sesungguhnya adalah bagaimana melawan emosi dalam dirinya sendiri. $^{30}$

\footnotetext{
${ }^{30}$ http://repository.isi-ska.ac.id/1086/ di akses Pada 28-11-2019
} 


\section{Pembahasan}

Film yang mengangkat tema budaya dan religius, akan memakai unsur-unsur yang menggambarkan sesuai tema. Jika sebuah film yang diangkat dari budaya Minangkabau, maka di dalam film tersebut terdapat hal-hal yang menggambarkan budaya Minangkabau yang diperlihatkan oleh seorang sutradara dengan berlatarkan rumah gadang, menggunakan bahasa Minang sebagai dialog dalam film, tokoh dalam film orang Minang dan menggunakan kostum masyarakat Minangkabau, serta konflik dalam film merupakan permasalahan yang terjadi pada saat ini di Minangkabau.

Film surau dan Silek menampilkan nilai-nilai religiusitas sebagai upaya dalam membangun karakter masyarakat minangkabau, yang sejak dahulu hingga sekarang memiliki tatanan kehidupan masyarakat yang sangat ideal, yang didasari nilai-nilai, norma-norma adat dan agama Islam yang menyeluruh, dalam satu ungkapan adat, berbunyi Adat Basandi Syara'-Syara' Basandi Kitabullah. Adat dan syarak di Minangkabau merupakan merupakan benteng kehidupan dunia dan akhirat yang disebutkan dalam pepatah adat, "kesudahan adaik ka balairuang,kasudahan syarak ka akhiraik (titik akhir adat adalah ke balairung, titik akhir agama adalah ke akhirat). ${ }^{31}$ Mamangan ini menyiratkan teguhnya benteng orang Minangkabau yang terkandung didalam adat dan kokohnya perisai Islam yang di pagari oleh syarak. $^{32}$

Untuk mengetahui makna dibalik tanda-tanda yang terdapat dalam film surau dan silek, maka penulis melakukan analisis melalui pendekatan analisis semiotika Ferdinan De Saussure. Pengamatan terhadap sebuah tanda tak ubahnya mengamati sebuah makna atau maksud kenapa, mengapa dan bagaimana benda tersebut eksis.

\section{Film Sebagai Sarana Penyampai Pesan Moral dan Pendidikan Karakter}

Era teknologi berarti bahwa setiap orang berupaya mencari cara yang paling efektif dan efesien dalam melakukan setiap aktifitasnya. Hal ini juga akan berimbas pada tataran yang ada dalam upaya penanaman nilai-nilai spiritualitas dan karakter kepribadian seseorang. Film merupakan sarana atau fasilitas yang menunjang dan memudahkan dalam proses transformasi nilai-nilai, pesan moral dan pendidikan karakter. Sehingga beberapa jenis film merepresentasikan nilai sosial, pesan moral dan pendidikan karakter.

Menurut Poerdaminta Secara bahasa, karakter adalah tabiat, watak, sifat-sifat kejiwaan, akhlak, atau budi pekerti yang membedakan seseorang dengan orang lain. Secara istilah, karakter adalah sifat utama yang terukir dan menyatu dalam pikiran, perasaan,

\footnotetext{
${ }^{31}$ Kesudahan adat artinya keputusan adat itu berakhir pada musyawarah ninik mamak di balairung adat, sedangkan keputusan dari syarak atau agama baru akan di rasa akibatnya di akhirat nanti. Karena itu, adat yang mempedomani syarak niscaya akan terhindar dari perbuatan nista.

${ }^{32}$ H. Mas'oed Abidin, Tiga Sepilin, Suluah Bendang Dalam Nagari. (Yogyakarta: CV Gre Publishing, 2016), h. 10
} 
Journal of Islamic Education Policy Vol. 4 No. 2 Juli - Desember 2019

keyakinan dan perilaku seseorang, yang membedakannya dengan orang lain. Sedangkan pendidikan karakter adalah usaha mengukir dan mempatrikan nilai-nilai utama ke dalam diri peserta didik melalui pendidikan, endapan pengalaman, pembiasaan, aturan, rekayasa lingkungan, dan pengorbanan dipadukan dengan nilai-nilai intrinsik yang sudah ada dalam diri peserta didik sebagai landasan dalam berpikir, bersikap, berkeyakinan dan perilaku secara sadar dan bebas. ${ }^{33}$ Memasukan unsur-unsur pendidikan karakter ke dalam film, memberi arti bahwa film merupakan sarana yang paling efektif upaya pendidikan karakter dewasa ini.

Tujuan dari pendidikan karakter adalah terciptanya generasi yang unggul. Buya Mas'oed menjelaskan bahwa generasi unggul yaitu memiliki daya inovasi dan daya kreasi yang tinggi ditopang oleh budaya (tamaddun) yang luhur. Cahaya akal mesti diletakkan dibawah naungan wahyu agar berpadu kepintaran dengan kebijaksanaan. Berpadu pengetahuan dengan hidayah. Maka rahmat dan barakah dapat diraih. Ihsan dan kasih sayang dapat dicapai. Setidaknya ada beberapa poin yang menjadi catatan untuk mewujudkan generasi unggul, menurut Buya Mas'oed Abidin, maka keberadaan generasi unggul adalah tantangan dan menjadi harapan untuk meraih generasi yang berprestasi dan berepribadian luhur. Adapun defenisi generasi unggul menurut Buya Mas'ud Abidin adalah:

a. Generasi unggul adalah generasi dinamik yang tumbuh dengan kejelian akal disertai kejernihan budi pekerti.

b. Generasi unggul itu sanggup bersanding dan bertanding ditengah perubahan, karena memiliki sikap mandiri yang madani dengan menguasai ilmu pengetahuan dan teknologi. Apabila generasi kini dibiarkan terlena dan lupa membenah diri dengan kekuatan ijtima'i (kebersamaan), tentulah generasi itu akan dijadikan jarum kelindan didalam satu pertarungan gazwul fikri.

c. Generasi unggul memiliki akal budi yang jernih. Mampu menghadapi berbagai tantangan global. Mereka memiliki jati diri sesuai fitrah anugerah Allah, memiliki iman yang kuat dan selalu mengajak kepada kebaikan serta melarang yang berbuat kemungkaran.

d. Generasi unggul adalah ilmuan muda, cendikiawan yang perlu meningkatkan kualitas kepemimpinan dengan kemahiran tanzim Islami. Teguh Ubudiyyah dan Zikrullah, mampu menilai tekonologi informasi, mahir bergaul dan berkomunikasi, cakap menyelesaikan konflik, mampu menarik minat dan dukungan umat banyak serta berpolitik. Menguasai bahasa, falsafah dan sejarah. Mahir merancang dan mengurus. Mampu melatih dan membimbing. Memelihara kesinambungan proses pembelajaran generasi terdidik dengan paksi Islam. ${ }^{34}$

33 Prof. Dr. H. Maragustam, MA, Filsafat Pendidikan Islam Menuju Pembentukan Karakter. (Yogyakarta : Pascasarjana Fakultas Ilmu Tarbiyah dan Keguruan UIN Sunan Kalijaga, 2018), h. 248

${ }^{34}$ H. Mas'oed Abidin, Tiga Sepilin, Suluah Bendang Dalam Nagari. (Yogyakarta: CV Gre Publishing, 2016),h. 85-86 


\section{Analisis Semiotika Ferdinand De Saussure}

Dalam Terminologi semiotika, gambar di klasifikasikan sebagai penanda visual, yaitu sebagai bentuk $\mathrm{X}$, yang tersusun atas unsur-unsur yang bisa dilihat (bukan di dengarkan, dirasakan, dibaui, atau sebagainya). Sedangkan Y adalah petanda, yaitu tentang apa yang dimaksudkannya. Maka secara lebih rincinya dalam analisis Film Surau dan Silek, maka penulis mengambil Gambar dari beberapa adegan yang menginterpretasikan unsur-unsur pendidikan karakter.

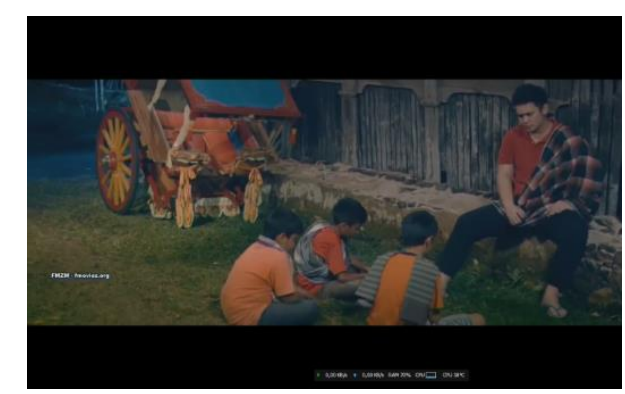

Gambar 1. Nasehat Seseorang Mamak Pada Kemenakan (sumber : Putra Chaniago, Film Surau dan Silek, 19 Desember 2019, Mahakarya Pictures)

Penanda : Rustam adalah mamak (paman) dari Adil. Rustam duduk di bandul, di halaman Rumah Gadang. Ia berbicara dihadapan tiga orang kemenakan (keponakan). Rustam sedang memberikan nasehat pada kemenakannya (Adil, Kurip, dan Dayat), dan mereka mendengarkan nasehat Rustam sambil merunduk.

Petanda : Scene ini merepresentasikan menerima nasehat yang disampaikan. Memberikan nasehat melalui perkataan adalah salah satu cara dalam Pendidikan Karakter. Dari ini memiliki makna pendidikan karakter dalam bentuk kecerdasan hati atau heart question.

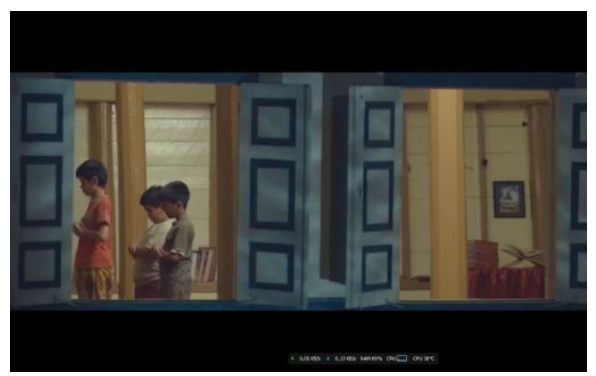

Gambar 2. Mendirikan Sholat Berjamaah Di Surau (sumber : Putra Chaniago, Film Surau dan Silek, 19 Desember 2019, Mahakarya Pictures)

Penanda : Tiga orang anak sedang mendirikan Sholat secara Berjama'ah, di sebuah masjid.

Petanda : Melaksanakan sholat adalah representasi dari muslim yang taat. Dengan semangat melaksanakan ibadah menandakan keseimbangan dalam diri seseorang. Mendirikan sholat termasuk pendidikan karakter. 
Journal of Islamic Education Policy Vol. 4 No. 2 Juli - Desember 2019

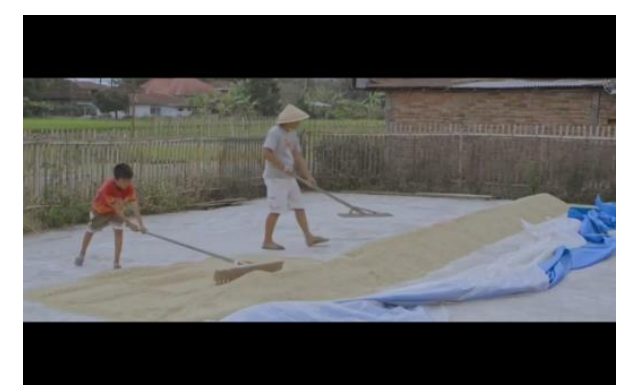

Gambar 3. Bekerja membantu Orang tua (sumber : Putra Chaniago, Film Surau dan Silek,

19 Desember 2019, Mahakarya Pictures)

Penanda : Dua orang yang sedang bekerja memegang mencakar padi, dan pakai topi tudung, untuk menjemur padi.

Petanda : Anak yang bekerja menandakan sikap berbakti dan mau bekerja keras membantu orang tua. Ini juga menandakan bahwa mau bekerja keras mengandung makna seseorang memiliki kecerdasan emosional atau emotional question.

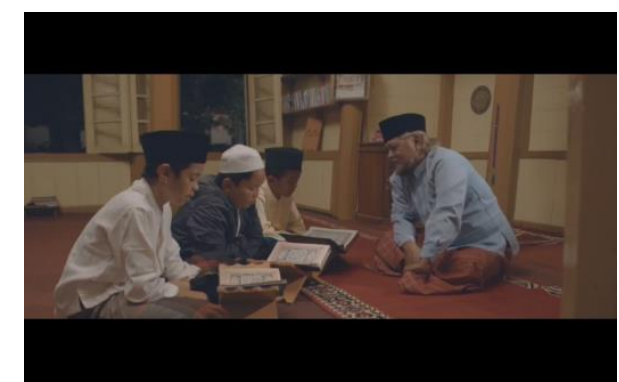

Gambar 4. Belajar mengaji

(sumber : Putra Chaniago, Film Surau dan Silek,

19 Desember 2019, Mahakarya Pictures)

Penanda : Seorang Laki-laki tua mengajar tiga orang anak membaca Al Qur'an.

Petanda : anak-anak remaja yang belajar mengaji menandakan bahwa belajar mengaji merupakan aktifitas yang dilakukan oleh remaja Minangkabau pada malam hari. Mengaji ilmu agama menjadi keharusan dalam pembentukan karakter pemuda di Minangkabau. Kepawaian seseorang dalam mengaji dan menuntu ilmu agama, memiliki makna seseorang yang harus memperdalam kecerdasan intelejen atau intelegent question dengan cara menuntut ilmu agama.

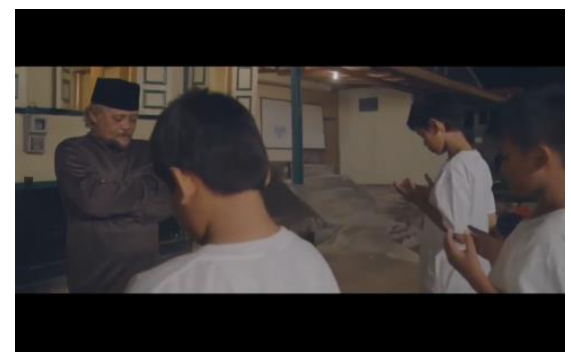

Gambar 5. Berdoa Sebelum memulai latihan (sumber : Putra Chaniago, Film Surau dan Silek, 19 Desember 2019, Mahakarya Pictures) 
Penanda : Seorang lelaki tua memimpin berdoa tiga orang anak untuk berdoa sebelum memulai.

Petanda : Berdoa sebelum melakukan kegiatan memiliki makna kecerdasan spiritual seseorang.

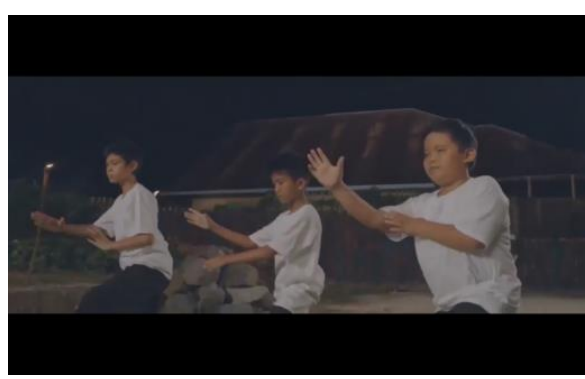

Gambar 6. Berlatih Silat

(Sumber : Putra Chaniago, film Surau dan Silek,

19 Desember 2019, Mahakarya Pictures)

Penanda : Tiga orang remaja memakai baju putih dengan gerakan silat dimalam hari. Petanda : Berlatih silat, salah satu pendidikan karakter di Minangkabau, lahirnya mencari kawan, bathinnya mencari tuhan. Memiliki makna kecerdasan hati, akal dan fikiran.

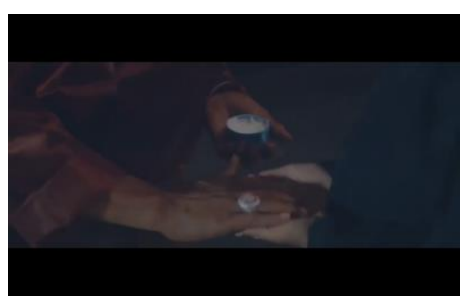

Gambar 6. Guru Silat yang berbuat Curang (Sumber : Putra Chaniago, Film Surau dan Silek, 19 Desember 2019, Mahakarya Pictures)

Penanda : "Kecurangan akan tumbang"

Petanda : Lahir silat mencari kawan, bathinnya silat mencari tuhan, seiring silat, sholat dan sholawat.

Kolaborasi nilai-nilai agama dan adat istiadat mengandung nilai edukasi, dengan adanya upaya memberikan pemahaman serta mengajak generasi muda untuk kembali mencintai budaya dan adat istiadat yang dimiliki. Inilah salah satu usaha yang dilakukan oleh Arif Malin Mudo untuk membentengi pemuda dari ancaman kerusakan moral. Pendidikan surau dan tradisi silek di Minangkabau adalah alternatif yang efektif dalam mengatasi kerusakan moral di Indonesia, terkhusus di Sumatera Barat.

Dalam film ini sang sutradara ingin menunjukan arti silek sebenarnya, yakni sebagai pembentuk kepribadian seorang anak manusia. Semakin pandai dia bersilat akan semakin mampu menguasai dirinya yang tercermin dari perangai dan karakter yang dimiliki. 
Journal of Islamic Education Policy Vol. 4 No. 2 Juli - Desember 2019

Silek adalah bagian dari masyarakat minang yang kental dengan adat dan nilai-nilai agama. Keterpaduan antara silat, sholat dan sholawat menuntun akhlak seseorang untuk menjadi generasi yang unggul, yaitu memiliki akal budi yang jernih, mampu menghadapi berbagai tantangan, memiliki jati diri sesuai fitrah anugerah Allah, memiliki iman yang kuat dan selalu mengajak kepada kebaikan serta melarang yang berbuat kemungkaran. ${ }^{35}$

Film ini merupakan wacana kritis terhadap kondisi generasi muda Minangkabau saat ini, yang mulai meninggalkan Surau dan melupakan silek sebagai bagian dari hidup mereka, untuk memunculkan semangat menjalankan perintah agama, melestarikan adat dan budaya, serta melahirkan generasi yang tangguh. Menurut Ulama Minangkabau, Buya Haji Mas'oed Abidin, generasi muda adalah kelompok besar ditengah satu bangsa yang semestinya menjadi generasi unggul (khaira ummah), merekalah yang akan memikul amanah sebnagai pelopor perubahan (agent of change) berbekal keyakinan dan keimanan kepada Allah SWT. Melaksanakan misi amar ma'ruf nahy munkar.

\section{Penutup}

Berdasarkan hasil analsisis semiotika Ferdinad de Saussure terdapat tanda-tanda yang ditampilkan pada film yang syarat dengan pendidikan karakter. Film ini tidak terlepas dari kemampuan sutradara dalam membaca situasi dan menyesuaikan dengan kondisi zaman. Film surau dan silek menampilkan beberapa adegan visual, dan teks yang memeliki makna pembelajaran dan pembentukan karakter terhadap pemuda. pembelajaran ini haruslah dilakukan secara terus menerus (kontinuitas) dan percontohan (uswah) yang baik, yaitu silek mengajarkan kesimbangan antara emosional question (kecerdasan emosional), spiritual question (kecerdasan spritual), intelegens question (kecerdasan intelejen) dan heart question (kecerdasan hati).

Film surau dan silek memeiliki tujuan wujud dakwah Islam Konservatif dalam menanamkan nilai-nilai religiusitas dan budaya Minangkabau dengan media massa melalui tanda-tanda yang ditampilkan oleh sutradara dalam serial film. Film surau dan silek dirasa menjawab tantangan alaf baru, yang dewasa ini dengan ditandai oleh (a). Mobilitas serba cepat dan modern, (b). Persaingan keras dan kompetitif, (c) komunikasi serba efektif. Adanya Film ini sebagaiF bagian dari dakwah yang mampu memanfaatkan teknologi media menjadi sarana menyampaikan pesan dan pendidikan pada generasi muda.

Demikianlah, semoga kita dapat melestarikan dan menghidupkan tatanan masyarakat yang beradat dan beradab di kalangan generasi muda Minangkabau dalam pranata sosial masyarakat hukum adat yang memiliki filosofi adat basandi syarak-syarak basandi Kitabullah (ABS-SBK) sebagai bagian dari memelihara puncak-puncak budaya nasional Indonesia.

${ }^{35}$ H. Mas'oed Abidin, Tiga Sepilin, Suluah Bendang Dalam Nagari. (Yogyakarta: CV Gre Publishing, 2016), h. 15 


\section{Daftar Pustaka}

Abidin, H. Mas'oed, Tiga Sepilin, Suluah Bendang Dalam Nagari. Yogyakarta: CV Gre Publishing, 2016.

Ardiyanto, Elvinaro, Komunikasi Massa Suatu Pengantar. Bandung:Simbiosa Rakatama Media, 2007

Biran, Misbach Yusra, Teknik Menulis Skenario Film Cerita. Yogyakarta: Pustaka Jaya, 2006.

Danesi, Marcel, Pengantar Memahami Semiotika Media. Yogyakarta: Jalasutra, 2010.

Erianto, Analisis Framing : Kontruksi, Ideologi dan Politik Media. Yogyakarta:PT LkiS, 2011 .

Lailatul Mufarihah, "Representasi Gender Dalam Film Tenggelamnya Kapal Van Der Wijk (Analisis Framing Model William A Gamson dan Andre Modigalani)" JURNAL ILMU KOMUNIKASI, Vol. 9 No. 1, April 2019.

McQuail, Dennis, Teori Komunikasi Massa Suatu Pengantar. Jakarta: Erlangga, 1994.

Madiyanto, Muslikh, Sinema Sastra : Mencari Bahasa Di Dalam Teks Visual, Jurnal Humaniora, Volume XV, No.2/2003

Maragustam. Filsafat Pendidikan Islam Menuju Pembentukan Karakter. Yogyakarta : Pascasarjana Fakultas Ilmu Tarbiyah dan Keguruan UIN Sunan Kalijaga, 2018

Nurgiantoro, Burhan, Teori Pengkajian Fiksi. Yogyakarta: Gajah Mada University Press, 2005.

Piliang, Yasraf Amir., Hipersmiotika : Tafsir Cultural Studis atas Matinya Makna. Yogyakarta: Jalasutra, 2003.

Prasetya, Arif Budi Analisis Semiotika Film dan Komunikasi, Malang: Intrans Publishing, 2019

Silmy Hayati, Dkk, "Struktur Tindak Tutur Nasihat Yang Terdapat Dalam Film Surau Dan Silek” LINGUISTIK: Jurnal Bahasa \& Sastra, Vol. 5 No.1 Januari-Juni 2020.

Siregar, Ashadi, Jalan Ke Media Film : Persinggahan Diranah Komunikasi-Seni Kreatif, Yogyakarta : LP3Y, 2007

Sobur, Alex. Semiotika Komunikasi. Bandung: Remaja Rosdakarya, 2006.

Sobur, Alex, Analisis Teks Media. Bandung: PT. Remaja Rosdakarya, 2006, Cet.ke 4

Sumarno, Marseli, Dasar-Dasar Apresiasi Film. Jakarta: Grasindo, 1996.

Vera, Nawiroh, Semiotika Dalam Riset Komunikasi. Bogor: Ghalia Indonesia, 2014.

Wibowo, Indiwan Seto Wahyu, Semiotika Komunikasi-Aplikasi Praktis Bagi Penelitian dan Skripsi Komunikasi. Jakarta: Mitra Wacana Media, 2011. 